\title{
Karaimi w szariackim sądzie na Krymie w XVII wieku'
}

\author{
Katarzyna Stefaniak-Rak \\ Uniwersytet im. Adama Mickiewicza, Wydział Neofilologii \\ Zakład Turkologii, Mongolistyki i Koreanistyki
}

\section{Karaims in the sharia court in the $17^{\text {th }}$ century Crimea}

\begin{abstract}
Summary: This article is devoted to Karaims in the $17^{\text {th }}$-century Crimea and focuses on a number of cases submitted before the sharia court in which Karaims took part. The main source of information in this area is the $10^{\text {th }}$ register (defter), which was written in Bakhchysarai (the capital of the Crimean Khanate) between 1666 and 1669/70 in the Gregorian calendar, that is in 1077-80 according to the Islamic calendar. It consists of 282 handwritten pages and records 589 court proceedings. Five percent of these cases are referred to in the records as cases involving Karaims. The main purpose of this analysis of was to find out what kind of information about Crimean Karaims can be found in the register.
\end{abstract}

Keywords: Karaims, Crimea, sharia court, Crimean Khanate, court register

XVII-wieczny Półwysep Krymski stanowiący zasadniczą część terytoriów Chanatu Krymskiego był kolebką wielu kultur, grup etnicznych i narodów. Zamieszkiwany w dużej części przez Tatarów Krymskich, był siedliskiem Nogajów, Czerkiesów, a oprócz nich również Greków, Ormian, Gruzinów i Żydów (Fisher 1978: 30). Trzeba tu wspomnieć, że określenie Yahūd̄̄ ‘Żyd’ często

\footnotetext{
$1 \quad$ Artykuł ten powstał dzięki finansowemu wsparciu Narodowego Centrum Nauki numer projektu 3810/B/H03/2011/40.
} 
wykorzystywane było także w odniesieniu do Karaimów. Obok wymienionych przez Alana W. Fishera narodowości Krym zamieszkiwali przedstawiciele innych narodów i grup etnicznych, takich jak chociażby Kazak 'Kozak' (5A)²; Rusī el-aşll 'Rusin' (10B); Macar 'Węgier' (70A), 'Acem 'Pers' (117B), 'Arab, el-'Arab 'Arab' (89B); Bog̀dan el-așll 'Mołdawianin' (23B); Dürzī ‘Druz' (45A); Kiıțī ‘Cygan' (129A); Kumuk 'Kumuk' (102A); Lipka ‘Tatar litewski’ (1A); Özü Kazag̀ı ‘Kozak znad Dniepru’ (29B), także Yahūd ‘ ‘̇̇yd/Karaim” (126B).

Dariusz Kołodziejczyk pisze, że C a n i b e k G i r e y ${ }^{4}$ w liście przymiernym użył sformułowania Tat bile Tavgaç, które „odnosiło się do wszelkich pozostałych poddanych chana, niezaliczanych do trzech głównych grup: Tatarów, Nogajów i Czerkiesów” we wcześniejszym fragmencie pojawia się jeszcze dopisek „określenie to [Tat - przyp. autorki] należy rozumieć, jako dotyczące nietatarskich poddanych chana: Greków, Włochów (...)” (2013: 87).

Karaimi byli liczącą się na Krymie mniejszością, która cieszyła się poważaniem i uznaniem chana. Jednym z miejsc ich osiedlenia było Czufut Kale ${ }^{5}$, jak nazywano starą twierdzę pod Bachczysarajem (Szapszał 1934: 2). U jej podnóża znajduje się rozległy wąwóz, a w nim stary cmentarz, na którym chowani byli karaimscy mieszkańcy twierdzy. Zabytkowe kamienne nagrobki przetrwały do dnia dzisiejszego.

W odróżnieniu od innych nie-muzułmanów (chrześcijan) Karaimi zamieszkiwali Krym na szczególnych warunkach. Posiadali między innymi prawo do wewnętrznej autonomii i bycia włodarzami Czufut Kale, dawnej stolicy chanatu. Dodatkowo cieszyli się licznymi ulgami podatkowymi (Fisher 1978: 34). Pisze o tym również Tadeusz Kowalski w recenzji poświęconej Karaimom monografii autorstwa Hadży Seraji Szapszała, która ukazała się w roku 1928 w Turcjí: „Stosunek Karaimów do ich nowych władców [dynastia Girejów - przyp. autorki]

2 Dane zebrane przez autorkę z protokołów z XVII-wiecznej księgi sądowej numer 10 (Aș-Șuqūq aš-šari ìyya wa as-siğillāt al-mar iyya cz. 10), o której mowa będzie w dalszej części artykułu. Numery w nawiasach odnoszą się do konkretnych stron rękopisu, na których wymieniane są podane narodowości/grupy etniczne. Litery A, B odnoszą się do stron lewa - verso (A), prawa - recto (B).

3 Wątek ten zostanie omówiony w dalszej części artykułu.

4 Chan Ca n i b e k G i r e y panował w Chanacie Krymskim w latach 1020-1033 oraz 1037-1045 roku hidżry.

5 Oprócz Czufut Kale Karaimi zamieszkiwali też w innych miastach takich jak: Bachczysaraj, Keffe, Gözlev i Mangub.

6 Antologia Türk Yhl 1928 pod redakcją Yusufa Akçuraoğlu, w której znalazła się monografia Szapszała (Şapşaloğlu) Kırım Karâ̂ Türkleri, została niedawno wznowiona: 
układa się jak najpomyślniej. Karaimi cieszą się zupełną swobodą religijną i zajmują w służbie chanów krymskich ważne stanowiska, między innemi stanowisko zarządców mennicy państwowej." (1929: 4).

Źródłem wiedzy o kulturze, życiu i zwyczajach Karaimów zamieszkujących Krym w XVII wieku mogą być relacje z tamtego okresu, tj. choćby księgi podróżnicze. Wśród nich jest dzieło سياحــ (Seyāhatnāme - Księga Podróży) autorstwa Ev li y i Ç e l e b i e g o, który opisywał swe wrażenia po odwiedzeniu różnych rejonów świata, w tym Półwyspu Krymskiego. W tłumaczeniu fragmentów Ksiegi Podróży dokonanym przez Zygmunta Abrahamowicza znajdujemy wzmianki dotyczące Karaimów, których podróżnik nazywa Żydami: „Wszelako wszyscy ci żydzi są wyznania karaimskiego. Inni żydzi nie lubią żydów tego wyznania. Ci zaś nie wiedzą, co to jest koszerne i trefne w potrawach, a mięso jedzą wszelakiego rodzaju (...). Żydzi ci to co prawda izraelici i mozaiści, ale Torę i Psałterz czytają. Języka żydowskiego nie znają oni zupełnie i mówią tylko po tatarsku. Nie noszą oni kapeluszy, lecz kołpaki tatarskie." (1969: 262) i dalej: „(...) Żydzi mieszkają w górnym Czufudkalesi i tam też mają swoją świątynię zwaną synago "” (1969: 293).

Informacje o poszczególnych Karaimach w XVII wieku, miejscach ich zamieszkania, imionach, interakcjach, w jakie wchodzili z innymi mieszkańcami Krymu, stanowiące podstawę artykułu znaleźć można w księgach sądowych z tamtego okresu. Aby przejść do tego zagadnienia należy jednak w paru zdaniach opisać funkcjonowanie administracji sądowej na Krymie, która stworzona została na wzór administracji Imperium Osmańskiego. Chanat Krymski podzielony był na okręgi sądowe zwane kaza, które podlegały kadim ${ }^{8}$. Kadi miał swych pomocników zwanych naibami, którzy przeprowadzali rozpoznanie, byli odpowiedzialni za ściąganie podatków, prowadzili w zastępstwie kadiego niektóre sprawy w terenie. Często pełnili też funkcję tzw. świadków zdarzenia, o czym będzie jeszcze mowa w dalszej części artykułu. Oprócz nich ważną rolę pełnili subaşı, którzy byli odpowiedzialni za utrzymanie porządku publicznego

Türk Ylh 1928. Toplayan: Akşuraoğlu Yusuf, red. Arslan Tekin, Ahmet Zeki İzgöer, Ankara: Türk Tarih Kurumu, 2009.

7 Jak podaje Abrahamowicz, wyraz synago jest skrótem od greckiego słowa synagoge 'zbiór; zgromadzenie ', współcześnie mianem tym zwykło się określać świątynie żydowskie. Abrahamowicz nie ma jednak wątpliwości co do tego, że Evliya Çelebi znał słowo kienesa, określenie właściwe dla świątyń karaimskich (1969: 445).

8 Sędzia sprawujący urząd w danym okręgu sądowym kaza, wyznaczany w celu potwierdzania transakcji handlowych, rozsądzania sporów, rozstrzygania w sprawach spadkowych i innych' (IA24: 66-71). 
(Stefaniak-Rak 2013: 124-125). Księgi sądowe9 spisywane przez protokolantów to rejestry spraw wnoszonych do instytucji sądowniczych. Do sądów zgłaszali się głównie Tatarzy Krymscy, choć spotyka się też przedstawicieli wielu innych narodowości i grup etnicznych. Te, które udało się odnaleźć w 10. księdze, zostały wymienione wyżej przy okazji wyszczególniania mieszkańców Krymu. Możliwe, że w pozostałych księgach występują jeszcze inne, nieuwzględnione $\mathrm{w}$ tym artykule.

Kolekcja XVII-wiecznych ksiąg sądowych z Krymu wraz z ich wersją elektroniczną jest częścią księgozbioru Biblioteki Narodowej w Sankt-Petersburgu ${ }^{10}$. W jej skład wchodzi wspomniana 10. księga. Została spisana przez kilku protokolantów (o czym świadczą różne charaktery pisma, których użyto w zapiskach).

Protokoły w niej zawarte były odnotowywane za panowania chana Adila Gireya ${ }^{11}$ w latach 1077-1080 hidżry. Informacja o latach, w których dokonywano zapisów w księdze została umieszczona na okładce, prawdopodobnie w chwili katalogowania tomu w bibliotece. W tekście źródłowym pierwsza wzmianka o dacie pojawia się na stronie 141B: (...) sene 1077 - '(...) rok 1077 (hidżry)'. Na następnej stronie 140A dodatkowo podany jest miesiąc Rebiülevvel sene 1077 - 'Rebiül-evvel, rok 1077 (hidżry)'. Po przeliczeniu na kalendarz gregoriański daje to wrzesień 1666 r. Ostatnie notatki w księdze powstały w roku 1079 (5B) i 1080 (3A). Nie został podany dzień, ani miesiąc, co uniemożliwia dokładne określenie daty według kalendarza gregoriańskiego. Trzeba uznać, że jest to rok 1669 lub 1670 (do miesiąca maja, w którym 1080 rok hidżry dobiega końca). W 10. księdze odnotowano 589 protokołów przeróżnej treści, dotyczących np. postępowań spadkowych, potwierdzeń udzielenia pełnomocnictw, sporów sąsiedzkich, sprzedaży, nabycia ziemi, zwierząt, przypadków zabójstw i pobić. O kwestiach związanych z tematyką ksiąg sądowych pisze również Seraja Szapszał w swym artykule o krymskich Karaimach. Opisując ich zawartość, wymienia sprawy sądowe, bieżące wydarzenia, kwestie ekonomiczne i zagadnienia dotyczące społeczności (Şapşaloğlu 2009: 625).

W omawianej księdze występuje dwadzieścia sześć protokołów spraw z udziałem Karaimów. Stanowi to około pięciu procent wszystkich odnotowanych w tym tomie zapisów. Notatki są dość skrótowe i występują w nich standardowe formuły. Zawierają dane osobowe stron postępowania (imiona,

9 Inne funkcjonujące nazwy to defter, sidzil (tur. sicil, sicill).

10 Wersja elektroniczna zbioru dostępna jest także w Bibliotece im. I. Gaspryńskiego w Symferopolu.

11 Chan Adil Girey panował w Chanacie Krymskim od 1076 do 1081 roku hidżry. 
imiona ojców), często także miejsce, z którego przybyły. Są to sprawy, w których obie strony postępowania to Karaimi bądź jedną ze stron są Karaimi, drugą zaś Tatarzy lub przedstawiciele innych narodowości/grup etnicznych. Ronald Jennings pisze: „nie-muzułmanie mieli nie tylko prawo, lecz i obowiązek udziału w sprawach założonych przez muzułmanów. Mieli możliwość przedstawienia własnej wersji zdarzenia, nawet jeśli utracili dowód, który potwierdzał ich wersję" (1978: 252). Częścią mniej formalną jest ten fragment zapisu, w którym poszczególni powodzi i pozwani zeznają, w jakiej sprawie przybyli do sądu. Następnie opisywane są kolejne czynności procesowe np. wezwanie do złożenia przysięgi, że dana sytuacja miała miejsce, wskazywanie i doprowadzanie świadków mogących potwierdzić wersję którejś ze stron. Przeważnie odnotowywana była także decyzja podjęta w konkretnej sprawie oraz podpisy şuhūd el-ḥall - świadków postępowania (zdarzenia), którzy brali udział w konkretnej sprawie (część świadków była etatowa). W 10. księdze nie mamy do czynienia z przypadkiem, aby jakiś Karaim został wymieniony jako świadek zdarzenia. Funkcję tę zwyczajowo pełnili muzułmanie, wśród których znajdowali się emerytowani sędziowie, urzędnicy, pomocnicy sędziów i inni. W odróżnieniu od świadków stron postępowania, którzy przybywali do sądu w celu złożenia stosownych zeznań, świadkowie zdarzenia czuwali nad prawidłowym przebiegiem przewodu sądowego (Akgündüz 2009: 175-176).

We wspomnianej księdze, podobnie jak ma to miejsce u Ev li y i Ç e le b i e g o, występuje sformułowanie Yahūdī, np. Bağçesarāy ḳażāsina tābi kạal'e sākinlerinden İlyā veled-i Mortuhay nām Yahūdī (...). (69B) 'spośród mieszkańców twierdzy przynależnej do okręgu Bachczysaraj Żyd o imieniu İlya syn Mortuhaya (...)'. W tym miejscu warto też wspomnieć, że „dawniej zarówno na Krymie, jak i w Polsce (...), Karaimów nazywano obok rdzennych wyznawców religji mojżeszowej (...) ogólnem mianem Żydów. (...) zjawisko to miało miejsce nie tyle w życiu codziennym (...), ile w dokumentach oficjalnych.” (Szapszał 1929: 19-20). Administracja Chanatu, jak i Turcji Osmańskiej nie rozróżniała Karaimów i Żydów, lecz traktowała ich jako jedną grupę wyznaniową. Rozróżnienie Karaima od Żyda w tekstach źródłowych z XVII wieku przysparza wiele trudności. W sytuacji, gdy brak innych danych, np. dotyczących miejsca zamieszkania/pochodzenia (np. Czufut Kale), karaimskiego imienia lub innych danych dotyczących konkretnej osoby, jednoznaczne stwierdzenie, iż była ona Karaimem, jest praktycznie niemożliwe. Zagadnienie to porusza także Rafał Witkowski w artykule poświęconym Karaimom w Wielkim Księstwie Litewskim powołując się na artykuł Mariusza Pawelca: „określenie «Judaeorum» odnosi się do wyznających religię starotestamentową tureckich Karaimów, nie zaś etnicznych Żydów." (2013: 220). 
Większość spraw z udziałem Karaimów dotyczy kwestii finansowych: pożyczek, zastawów, zwrotu należności, jak chociażby ta ze strony $137 \mathrm{~B}^{12}$ :

Działo sie tak, że $w$ sądzie osoba o imieniu Okı Tok z plemienia Czerkiesów w obecności $\dot{Z} y d a^{13}$ Avrahima z chronionego miasta Bachczysaraj złożyła słowne wyjaśnienie: przyjałem i pobrałem całkowitą należna mi cześś $z$ dziesięciu akça i czterdziestu kuruszy - powiedział. Zapisano, iz wspomniany wyżej Żyd został zwolniony z powyższej kwoty pieniędzy. Miesiac Rebiü'l-evvel, rok tysiac siedemdziesiąty siódmy. Świadkowie zdarzenia:

Abd el-Baki efendi II Akay efendi $\|$ Abd el-Kerim Ahmed, syn Arslana efendi II Mevlud, syn Alego efendi II i inni obecni

Notatka ta stanowi potwierdzenie uregulowania należnej kwoty przez Avrahima i zwolnienie go ze zobowiązań finansowych względem osoby o imieniu Okı Tok. Na stronie 131B mamy zaś do czynienia z ustaleniami pomiędzy zarządcą a pracownikiem wakfu - fundacji przy meczecie:

Działo się tak, ze w sadzie zarządca wakfu i muezzin w meczecie Beyiş, muezzin Ali spośród mieszkańców chronionego miasta Gözlev w obecności Żyda imieniem Avraham, syna Baby ${ }^{14}$ : dałem dziesięć akça na procent temu oto Avrahamowi z zarządu wakfu wspomnianego meczetu, a on przez całe dwa lata nie przekazal ani procentów, ani żadnego akça. Powiedzial: $\dot{z} a$ dam sprawiedliwości zgodnie $z$ szariatem. Po zapytaniu wspomniany Żyd potwierdzif słowa wymienionego zarządcy wakfu. Zdarzenie zostało spisane na życzenie. Świadkowie zdarzenia: dobrze znany Esad efendi || Emrüllah efendi kadi z Bachczysaraju || Cuma Ali efendi $\|$ i inni

W protokole zapisanym na stronie 126B mowa jest o rozstrzygnięciu sporu zaistniałego pomiędzy Nogajem a Karaimem z twierdzy, a dotyczącego zaginionego konia. Spór ostatecznie został rozstrzygnięty na korzyść Nogaja:

Działo się, tak, że osoba imieniem Mirza Bek, syn Bek Taya $z$ Nogajów, Turków, w konfrontacji z İlya, synem Şemaya $z$ twierdzy ${ }^{15}$, obecnym tu, będacym strona $w$ sadzie: rok temu pewnej nocy zaginą nalezacy do mnie kon z połyskiem, oznaczony tamga. Zgłosiłem to do rejestru, znalazłem go $w$ rękach wspomnianego Żyda. Powiedziałem: zgodnie $z$ szariatem

12 Protokoły rozpraw występujące $\mathrm{w}$ artykule stanowią polskie tłumaczenie oryginalnych zapisów zaczerpniętych z 10. księgi sądowej z Krymu.

13 W tłumaczeniach wybranych protokołów określenie Yahūdī tłumaczono jako 'Żyd', a nie 'Karaim', choć pochodzenie z Bachczysaraju wskazuje, że z dużym prawdopodobieństwem był to Karaim.

14 Baba to imię występujące u Karaimów.

15 Chodzi o Czufut Kale. 
oczekuje się od sądu zabrania go z rąk tego Żyda. Po przesłuchaniu wspomniany Żyd odpowiedzial: kupiłem tego konia od Alego Mirzy. Od dwóch lat jest w moich ręach. Powiedzial: nie ma pewności, że takie zdarzenie miało miejsce. Dlatego też ze strony wspomnianego Mirzy Beka zażądano stosownego świadka na potwierdzenie jego słów. Spośród sprawiedliwych osoby o imieniu Abbas Halife, syn Isy i Mehmed Halife Musa: ten oto wspomniany koń z połyskiem jest własnościa Mirzy Beka. My jesteśmy świadkami tego zdarzenia, co więcej składamy zeznania, po czym każdy z nich złożył świadectwo zgodne z szariatem, które zostało złożone zgodnie z przyjętymi normami. Po zatwierdzeniu świadectw $i$ wyshuchaniu przysiegi, $i \dot{z}$ koń nie został $w \dot{z}$ aden sposób przetransportowany wspomnianemu Mirzie Bekowi, zapisano zasadzenie konia wymienionemu Mirzie Bekowi na Wielkiego i Potęznego Allaha. Na początku Rebiü'l-ahiri, rok tysiąc siedemdziesiaty siódmy. Świadkowie zdarzenia:

Arslan efendi | el-Hac Receb || Hașim efendi | Abd er-Rahman || Mehmed efendi | Ahmed Bek || el-Hac Abd er-Rahman Çelebi syn Haşima efendi \| Abd el-Latif Çelebi syn el-Hac Osmana \| Musalli Çelebi efend syn Halima agi $\|$ i inni

W księgach sądowych pojawiają się także spory o dobytek i mienie ruchome. Co ciekawe, wiarygodność zeznań potwierdzano wzywając świadków, którzy mieli uwiarygodnić wersje zdarzenia pozwanego/powoda. W sytuacjach, w których nie było możliwości przesłuchania świadków, dochodziło między innymi do obligowania stron postępowania (przeważnie pozwanego) do złożenia przysięgi na Boga (Allaha), iż zeznawał zgodnie z prawdą lub zdarzenie, o którym wspominała jedna ze stron, rzeczywiście miało miejsce. Znaczenie składanej w obecności sędziego, protokolantów przysięgi uwiarygodniającej zeznania wyznawców innych niż islam religii (jak to było w przypadku Karaimów, Rusinów, Greków i innych) nie dawało gwarancji ich prawdomówności. Zagadnienie to nie było jednak przedmiotem badań w trakcie prac nad tym artykułem. Na stronie 70A możemy odnaleźć notatkę dotyczącą mienia przechowywanego w depozycie u Babaşa w Gözlev i konieczności złożenia przysięgi na Allaha. W tym miejscu warto też dodać, że w języku karaimskim używano słowa Allah na określenie Boga „Allah $n$ God (Q 169); аллах 'аллах, бог | Allah, Bóg | Allah, God' (KRPS 65, Ш) <Tur $\leftarrow$ Ar>” (Aqtay, Jankowski: 40). Nie we wszystkich językach mniejszości etnicznych, którym nakazywano składanie przysięgi na Allaha, używano słowa Allah w odniesieniu do Boga, jak to było u Karaimów.

Protokoły rozpraw sądowych zawierają dość lakoniczne informacje. Nie ma wzmianki o żadnych następstwach krzywoprzysięstwa, ani mijania się $\mathrm{z}$ prawdą lub stosowaniu innych niż obowiązujące w prawie szariatu formuł przysięg dla innowierców. 
Działo się tak, że w sadzie Żyd Avraham $w$ towarzystwie i obecności Żyda imieniem Babaşs złożył zeznanie: uprzednio $w$ depozycie u wspomnianego Babaşa $w$ Gözlev umieściłem stara kołdrę $i$ jeden ceber, stara barania skórę $i$ chuste, i czarna skórę, i cztery kawałki płótna, $i$ byka. Nadal żądam od wspomnianego Babaşa czterech kawałków tkaniny (i) byka, $i$ innych. Po przesłuchaniu (pozwany) miał zaprzeczyć, dlatego też wspomnianemu Babașowi zaproponowano złożenie przysiegi, którą złożył na Allaha. Po złożeniu przysiegi na Allaha orzeczono o oczyszczeniu wspomnianego Babaşa z zarzutów. Zaistniała sytuacje zapisano na życzenie. Świadkowie zdarzenia:

Ali efendi || Şakir efendi | Ahmed efendi || Şahbaz | Nasuh || Devlet Gazi | przybyły || i my inni zebrani

Sprawy z udziałem Karaimów przedkładane w sądach opartych na szariacie na Krymie zgłaszane były w celu potwierdzenia określonego stanu rzeczy, np. potwierdzenia sprzedaży, zakupu ziemi, dobytku, scedowania prawa własności na kogoś innego. Szczegółowe określanie granic działki, znajdującego się na niej dobytku oraz kwoty sprzedaż lub kupna stanowiło istotną część zapisów w rejestrze. Informacje te znaleźć można np. w zapisie na stronie 69A:

W sadzie Żyd İlya, syn Mortuhaya, jeden spośród mieszkańców twierdzy przynależnej do powiatu Bachczysaraj, w obecności Baby syna Şulomy, również mieszkańca wspomnianej twierdzy, złożyl zeznanie: powodem spisania $w$ księdze jest fakt, iż doprowadziłem do rzeczywistej sprzedaży temu oto wspomnianemu Babie za czterdzieści dwa kurusze kawałka należacego już do niego sadu, znajdujacego sie na miejscu bitwy $w$ Ak Yar przy czystym strumieniu, ze wszystkim, co do niego przylega i wszystkimi prawami i drzewami owocowymi i innymi drzewami, którego granice sa następujace: na południu Ak Yar, na północy moja posesja, na wschodzie posesja starego Yaku i na zachodzie posesja wspomnianego Baby. Po pobraniu należnych pieniędzy przekazalem sprzedana nieruchomość. Następnego dnia wspomniany sad stał się własnościa nabytą wymienionego powyżej Baby. Powiedzial: zgodnie z wola i życzeniem jest jego właścicielem i może go użytkować. Wspomniany Baba wszystkimi swymi słowami i zeznaniami mial dowieść prawdziwości wyjaśnień złożonych przez wspomnianego İlyę. Orzeczono o prawdziwości sprzedaży i zakupu. Zgodnie z życzeniem sporządzono ten oto dokument, który zostal przekazany na ręce zainteresowanego, $w$ zwiazku z tym, co zostało ujawnione i wspomniane [... $]^{17}$. W połowie miesiaca Zil'hicce, rok tysiąc siedemdziesiąty siódmy. Świadkowie zdarzenia:

Mehmed syn Alego || chluba nauczycieli Şakir efendi | Ahmedi efendi || Sefer syn Hasana || Osman syn Mustafy || Ahmed syn Ömera \| Osman syn Alego \| Abd er-Rahman

16 Babaş to imię występujące u Karaimów, składa się z rdzenia Baba i sufiksu -ş, wykorzystywanego do zdrabniania imion.

$17 \quad$ Nie udało się odczytać fragmentu tekstu. 
syn Hasana || Mehmed syn Hüseyina || Mustafa syn Sultan Keldiego || Osman syn Hasana || Devlet Ali syn Devlet Keldiego || Abd Allah efendi | [... ${ }^{18}$ Abdi efendi

Podobną sprawę odnotowano również na stronie 38B, gdzie zakupu ziemi dokonywał Mustafa efendi w imieniu własnym oraz żony, która udzieliła mu swojego pełnomocnictwa:

Działo się tak, że w sadzie spośród Żydów Mortehay syn Isaka w obecności Mustafy efendiego syna Mevluda efendi złożył zeznanie i dobrowolne wyjaśnienia: podaje się do wiadomości granice należacego do mnie sadu położonego nad rzeka Belbek $w$ kierunku kamiennego mostu: od południa [przylega] do posiadłości Zekeriyi i od wschodu do posiadłości Çubara Şölema, i od pólnocy do posiadłości wspomnianego Mustafy efendiego, i od zachodu osiaga swój kres przy posiadłości [brak imienia]. Połowę tego oto należacego do mnie sadu, $z$ wytyczonymi z czterech stron granicami, drzewami owocowymi i wszystkimi prawami i horyzontem sprzedałem za pięćdziesiąt kuruszy i przekazalem wspomnianemu Mustafie efendi, a pozostała połowę Cihan Şah Bike, mocodawczyni wspomnianego efendiego. Następnie przyjałem i $w$ całości pobrałem wspomniana kwote. Wspomniany efendi we własnym imieniu oraz $w$ imieniu wspomnianej Cihan Şah Bike będac upoważnionym przekazal [środki finansowe]. Następnego dnia wspomniana nieruchomość stała się własnościa zakupiona wspomnianego efendiego i jego wspomnianej mocodawczyni. Powiedzial: zgodnie $z$ wola i życzeniem sa jej właścicielami i moga ja użytkować. Po zapytaniu wspomniany Mustafa miał od początku do końca potwierdzić złożone przez wspomnianego zeznajacego wyjaśnienia. Orzeczono więc o prawidłowości sprzedaży i zakupu. Wspomniana zaistniała sytuacje zapisano. We wspomnianej dacie. Świadkowie zdarzenia:

chluba uczonych Hzzr efendi | nauczyciel || Abd er-Rahman efendi | kadi dla Kara Su || el-Hac Abd el-Baki | en-Nakkaş || Abd el-Halim aga | syn Mustafy agi || i inni zgromadzeni

Na stronie 40B znaleźć możemy adnotację dotyczącą sprawy, której przedmiotem był zakup niewolnicy. Kobieta miała jednak pewien defekt, który został niejako zatajony przez sprzedającego. Transakcja doszła do skutku, jednakże powód zabiegał o unieważnienie transakcji z uwagi na niezgodność towaru z opisem:

Działo się tak, że w sadzie Ahmed syn Abd Allaha w obecności İsaka syna Dawida wnióst przeciw niemu sprawe do sadu: te oto obecna $w$ sadzie niewolnice, Rusinke z pochodzenia imieniem Kel Zaman, zakupiłem od wspomnianego Żyda Isaka za sto trzydzieści kuruszy. Miała na samym czubku głowy parszywe miejsce, powstałe na skutek owrzodzenia, a nie na skutek łysienia. Zakupiłem ja pod warunkiem, że nie będzie łysa. Ponieważ nadal widoczna jest jej łysina, to postanowiłem ja pozostawić tymczasowo w opiece. Niech zostanie zadane pytanie. Powiedzial: moim celem jest anulowanie transakcji. Po zapytaniu wspomniany Isak

18 Jak wyżej. 
zaprzeczył oświadczeniu, jakoby warunkiem $w$ chwili zawierania umowy było posiadanie włosów. Mial odpowiedzieć: sprzedana przez mnie dziewczyna miała wadę. Zażadano więc od powoda stosownego świadka na potwierdzenie zakupu pod wspomnianym warunkiem. Wspomnianemu Żydowi, niemogacemu wskazać świadka, nakazano złożenie przysiegi, a nastęnie orzeczono o prawdziwości sprzedaży i zakupu, co zapisano. Spisano pod koniec Rebiü'l-ahiri, rok 1078. Świadkowie zdarzenia:

chluba uczonych | mufti || Abd el-Cemil efendi || Hasan | zarzadca wakfu || el-Hac Atmanay| aga || $i$ inni spośród zgromadzonych

Zapisy spraw wnoszonych do sądów opartych na szariacie na Krymie z udziałem Karaimów jako stron postępowania występują w 10. księdze sądowej sporadycznie, dostarczają jednak wielu informacji. Dowiadujemy się z nich, z jakimi problemami borykano się wówczas, zyskujemy wiedzę o nadawanych imionach, związkach pokrewieństwa pomiędzy poszczególnymi osobami, lokalizacji działek, sadów, ogrodów, dobytku ruchomym, miejscach zamieszkania bohaterów poszczególnych spraw. Z treści protokołów wspomnianego rejestru wiadomo też, że w rejestrach odnotowywano głównie sprawy z udziałem Karaimów i Tatarów, choć zdarzają się też przypadki, gdy obiema stronami są Karaimi dochodzący w sądzie szariackim sprawiedliwości w sprawach przeciwko wspólwyznawcom. Przed sądem regulowano również kwestie formalne związane ze sprzedażą i zakupem ziemi oraz innych dóbr.

Wnoszone do sądu sprawy z udziałem Karaimów dotyczą głównie mieszkańców okolic Bachczysaraju (przeważanie twierdzy Czufut Kale). Wymieniane jest też miasto G ö z l e v (obecnie Eupatoria). W przypadku kilku zapisków brak jest danych o miejscu pochodzenia stron postępowania. Opisany rejestr nie dostarcza również też szczegółowych informacji o Karaimach zamieszkujących inne miasta czy wsie na Krymie, z wyjątkiem wsi ‘Abbas Bagalagì.

Księgi sądowe z Krymu dają możliwość lepszego poznania statusu Karaimów, ich kontaktów i relacji z innymi mieszkańcami chanatu poprzez dokumentowanie spraw $\mathrm{z}$ ich udziałem. Informacje zawarte $\mathrm{w}$ protokołach stanowią rzetelne źródło wiedzy o realiach życia mieszkańców, administracji sądowej, profesjach, jednostkach monetarnych, narodowościach XVII-wiecznego Chanatu Krymskiego.

\section{Bibliografia}

Abrahamowicz, Zygmunt, Dubiński, Aleksander, Płaskowicka Rymkiewicz, Stanisława [tłum.], Księga podróży Ewliji Czelebiego (Wybór), Warszawa: Książka i Wiedza, 1969. Akgündüz, Ahmed, İslam ve Osmanh Çevre Hukuku, İstanbul: Osmanlı Araştırmaları Vakfı Yayınları, 2009. 
Aqtay, Gulayhan, Jankowski, Henryk, A Crimean Karaim-English Dictionary, Poznań: Katedra Studiów Azjatyckich Uniwersytet im. Adama Mickiewicza, 2015.

Fisher, Alan W., The Crimean Tatars, Stanford: Hoover Institution Press, 1978.

Jennings, Ronald, Zimmis (Non-Muslims) in Early 17th Century Ottoman Judicial Records: The Sharia Court of Anatolian Kayseri, ,Journal of the Economic and Social History of the Orient" 1978, t. 21, z. 3, s. 225-293.

Kołodziejczyk, Dariusz, Zaproszenie do osmanistyki. Typologia i charakterystyka źródeł muzulmańskich sąsiadów dawnej Rzeczypospolitej: Imperium Osmańskiego i Chanatu Krymskiego, Warszawa: Wydawnictwo DiG, 2013.

Kowalski, Tadeusz, Turecka monografja o Karaimach krymskich, „Myśl Karaimska” 1929, t. II, z. 2, s. 1-8.

Stefaniak-Rak, Katarzyna, Some Notes on the Seventeenth-Century Crimean Khanate on the Basis of Judicial Records, [w:] Turkey, Kazakhstan and the Crimea. Ten Years of Turkology in Poznań, Henryk Jankowski [red], Poznań 2013, s. 123-132.

Szapszał, Seraja, Karaimi w służbie u chanów krymskich, „Myśl Karaimska” 1929, t. 2, z. 2, s. $5-22$.

Szapszał, H. Seraja, Adam Mickiewicz w gościnie u Karaimów, „Myśl Karaimska” 1934, t. 10, z. 10, s. 1-10.

Şapşaloğlu, Sereya, Kırım Karâ̂ Türkleri, [w:] Türk Ylı 1928. Toplayan: Akçuraoğlu Yusuf, red. Tekin, Arslan, İzgöer, Ahmet Zeki, Ankara: Türk Tarih Kurumu, 2009, s. 605-650.

Topaloğlu, Bekir [red.], 1988-2002. Türkiye Diyanet Vakfı İslâm Ansiklopedisi 1-25. İstanbul, Ankara: Türkiye Diyanet Vakfı İslâm Ansiklopedisi. (IA24: 66-71).

Witkowski, Rafal, Some Remarks on the History of the Karaites, „Karaite Archives” 2013, t. 1, s. 211-241. 


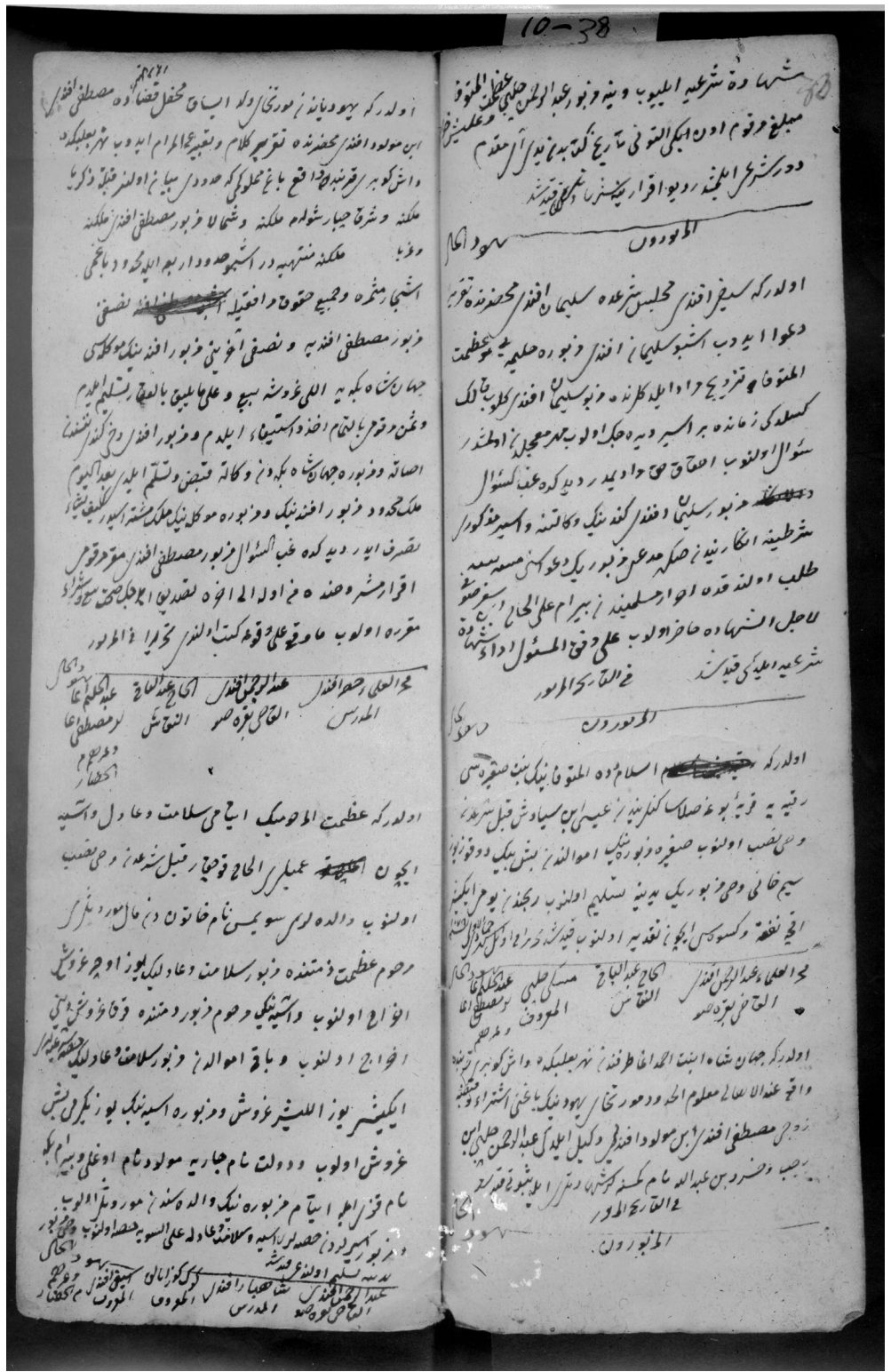

Ryc. I. Przykładowe karty księgi sądowej nr 10 (XVII w.) zawierające zapisy spraw z udziałem Karaimów, cz. 1 


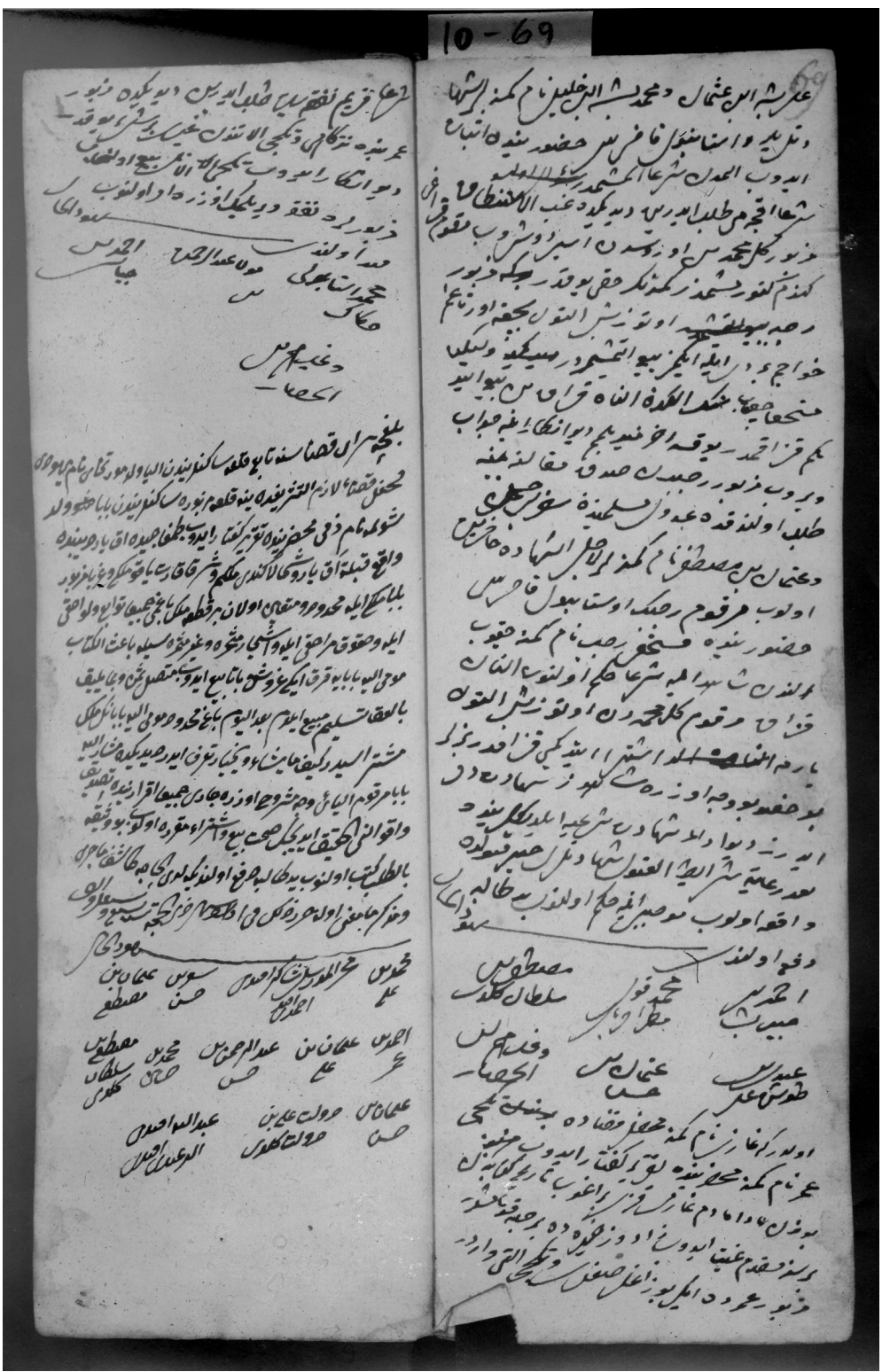

Ryc. 2. Przykładowe karty księgi sądowej nr 10 (XVII w.) zawierające zapisy spraw z udziałem Karaimów, cz. 2 


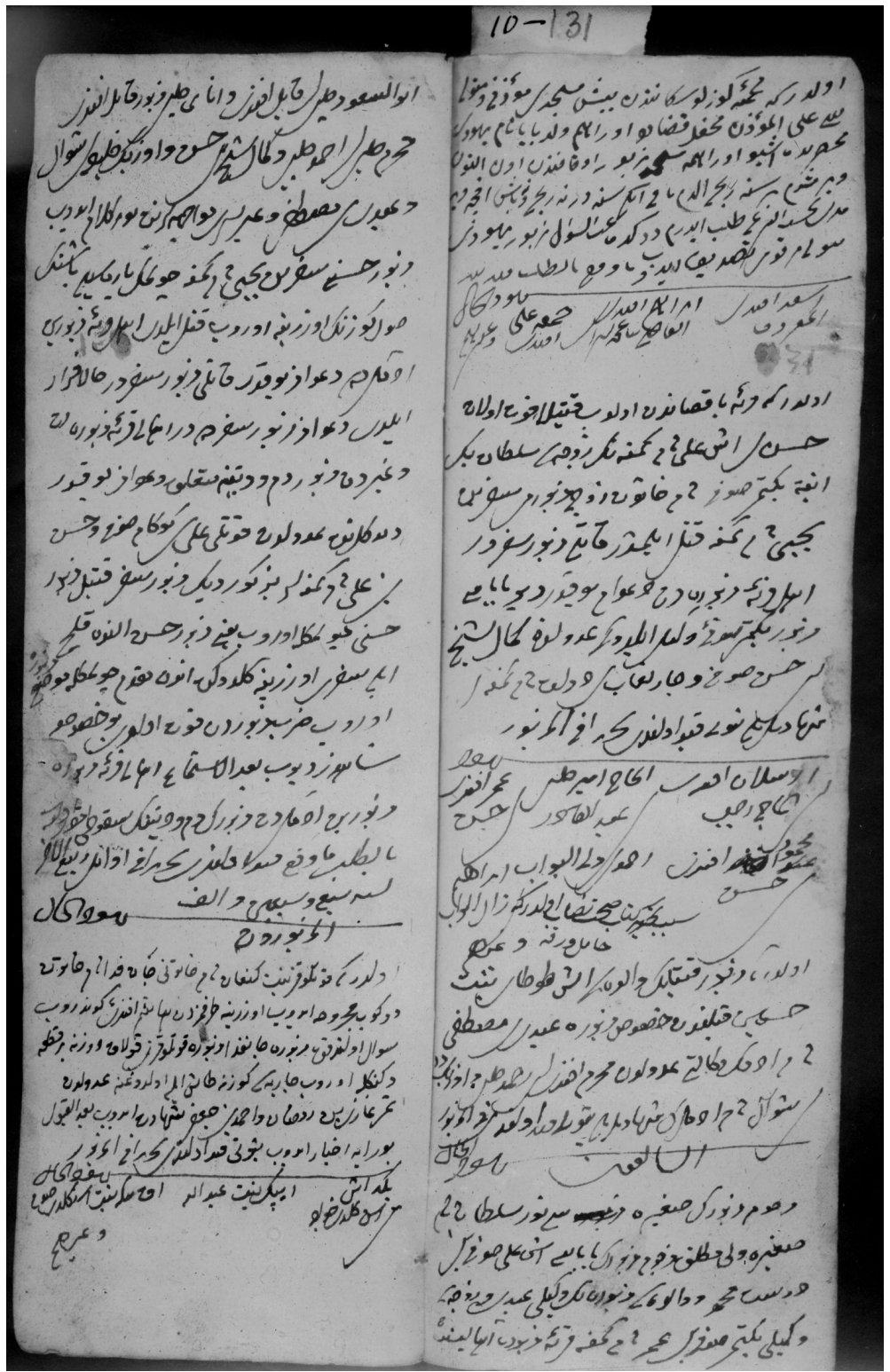

Ryc. 3. Przykładowe karty księgi sądowej nr 10 (XVII w.) zawierające zapisy spraw z udziałem Karaimów, cz. 3 